\title{
Impacts of Urbanization on Land Use Pattern and Environment: A Case Study of Ajmer City, Rajasthan
}

\author{
Bhanu Priya Chouhan ${ }^{1}$ and Monika Kannan ${ }^{2}$ \\ ${ }^{1}$ Master of Science, ${ }^{2}$ Head of the Department \\ Department of Geography, Sophia Girls’ College, Ajmer, Rajasthan, India \\ E-Mail: bhanupriyac77@gmail.com
}

\begin{abstract}
The world is undergoing the largest wave of urban growth in history. More than half of the world's population now lives in towns and cities, and by 2030 this number will swell to about 5 billion. 'Urbanization has the potential to usher in a new era of wellbeing, resource efficiency and economic growth. But due to increased population the pressure of demand also increases in urban areas' (Drakakis-Smith, David, 1996). The loss of agricultural land to other land uses occasioned by urban growth is an issue of growing concern worldwide, particularly in the developing countries like India. This paper is an attempt to assess the impact of urbanization on land use and land cover patterns in Ajmer city. Recent trends indicate that the rural urban migration and religious significance of the place attracting thousands of tourists every year, have immensely contributed in the increasing population of city and is causing change in land use patterns. This accelerating urban sprawl has led to shrinking of the agricultural land and land holdings. Due to increased rate of urbanization, the agricultural areas have been transformed into residential and industrial areas (Retnaraj D,1994). There are several key factors which cause increase in population here such as Smart City Projects, potential for employment, higher education, more comfortable and quality housing, better health facilities, high living standard etc. Population pressure not only directly increases the demand for food, but also indirectly reduces its supply through building development, environmental degradation and marginalization of food production (Aldington T, 1997). Also, there are several issues which are associated with continuous increase in population i.e. land degradation, pollution, poverty, slums, unaffordable housing etc. Pollution, formulation of slums, transportation congestion, environmental hazards, land degradation and crime are some of the major impacts of urbanization on Ajmer city. This study involves mapping of land use patterns by analyzing data and satellite imagery taken at different time periods. The satellite images of year 2000 and 2017 are used. The change detection techniques are used with the help of Geographical Information System software like ERDAS and ArcGIS. The supervised classification of all the three satellite images is done by ERDAS software to demarcate and analyze land use change.

Keywords: Urbanization, Urban Sprawl, Land Degradation, Environmental hazards, Crime
\end{abstract}

\section{INTRODUCTION}

Urbanization refers to the gradual increase in the proportion of people living in urban areas. In 1800 only about $2 \%$ of the world's population lived in urban areas which has grown from $2 \%$ to $50 \%$ in just 200 years and it is estimated to reach up to $66 \%$ till 2050. Urbanization in India began to accelerate after independence, due to the country's adoption of a mixed economy, which gave rise to the development of the private sector. Urbanization is taking place at a faster rate in India. Population residing in urban areas in India, according to 1901 census, was $11.4 \%$. This count increased to $28.53 \%$ according to 2001 census, and crossing 30\% as per 2011 census, standing at 31.16\%.

\section{STUDY REGION}

Ajmer originally known as Ajayameru is an administrative center in the state of Rajasthan, which is located at distance of about $355 \mathrm{~km}$ in the southwest part of New Delhi, the Capital of India (Figure 1).

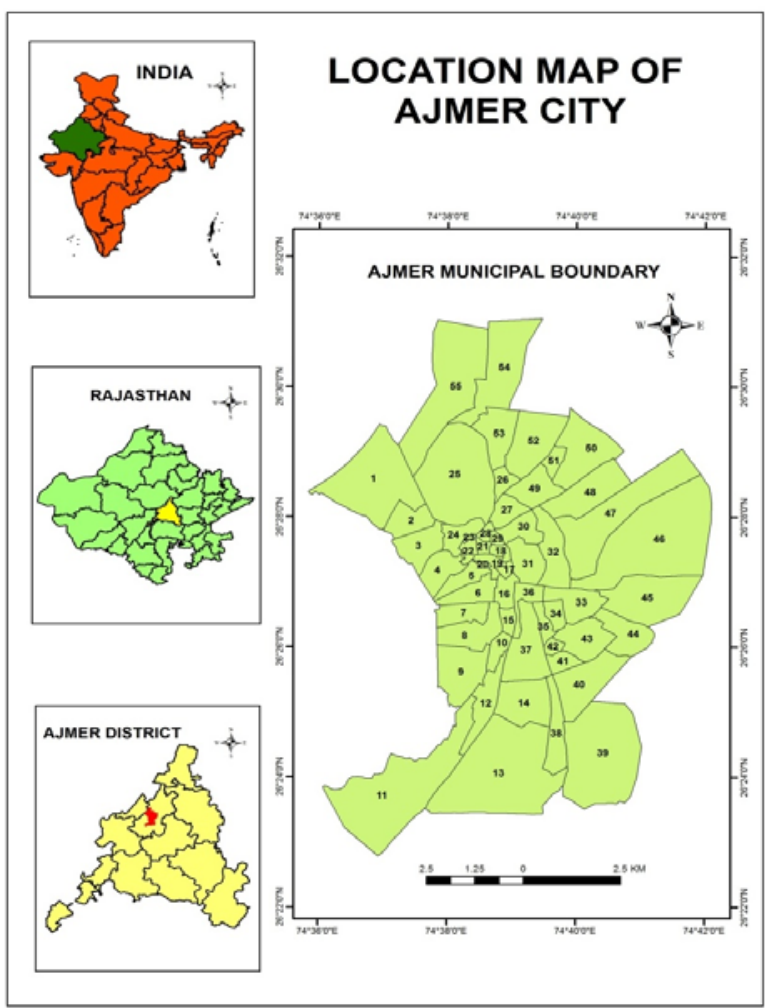

Fig 1 Location of Ajmer City

The eastern portion of the district is generally flat, broken only by gentle undulations. The western parts, from northwest to south-west, are intersected by the Aravalli Range. Many of the valleys in this region are sandy deserts, part of India's Thar Desert, with an occasional oasis of cultivation. Some fertile tracts are also present; among these is the plain on which lies the town of Ajmer. This valley has an artificial lake called the Anasagar Lake and is protected by the massive walls of the Nagpathar range or Serpent rock, which forms a barrier against the sand. 


\section{OBJECTIVES OF THE STUDY}

In line with the development of urbanization, arable land is decreasing dramatically, with serious ramifications for long-term agricultural sustainability. Unfortunately, in Ajmer, planning standards and regulations do not pay adequate attention to or exclude agriculture from urban land use systems. Thus, this study intended to build consensus on the need for agricultural land protection in the context of urbanization.

1. To assess the impact of Urbanization and Urban Sprawl on the growth of Ajmer city of Rajasthan.

2. To undertake Change Detection on land use pattern from the year 2000 to 2017 of Ajmer city.

3. To investigate the accelerating rate of Environmental Concerns and Hazards through urban growth in Ajmer city.

\section{DATA AND METHODS}

The nature of research in this paper, which describes and explores changes in land use pattern in the context of urbanization in one of the divisions of Ajmer district, which includes 60 wards of Ajmer city, favors the case study strategy - an empirical inquiry at first place that examines a contemporary phenomenon within the real-life context beyond researchers' control as well as the use of modern techniques by using GIS software like Arc GIS and ERDAS (Bhatta B., 2010).

This study illustrates the spatio-temporal dynamics of urban growth and land use changes in Ajmer city of Rajasthan from the year 2000 to 2017. Landsat satellite imageries of two different time periods 2000 and 2017 were used to know the changes in land use pattern. Supervised classification methodology has been employed using maximum likelihood technique (change detection) in ArcGIS 10.2 software. By applying classification methods to the satellite images, five main types of land use were extracted; built-up area, agricultural area, forest, wasteland and water body. Then the area coverage of all the land use type at different points in time (2000 and 2017) were measured.

\section{A. Data Collection}

1. The satellite imagery of Ajmer city from the satellite images of the year 2000 and 2017 have been collected through USGS website.

2. Master Plans of Ajmer city have been taken into consideration.

3. Ward wise maps and data have been collected from Ajmer Development Authority and Ajmer Nagar Nigam.

\section{RESULTS AND DISCUSSION}

Ajmer has evolved around a religious core synonymous with the city. The historic aspects of Ajmer tell about its glory. Ajmer city is centrally located in the state and important from historical, religious, academic and administrative point of view. As per data released by
Govt. of India for Census 2011, Ajmer is an Urban Agglomeration coming under category of Class I UA/Towns. Ajmer city is governed by Municipal Corporation and is situated in Ajmer Urban Region. The total population of Ajmer UA/Metropolitan region is 551,101 . The male population of which is 283,072 while female population is 268,029 .

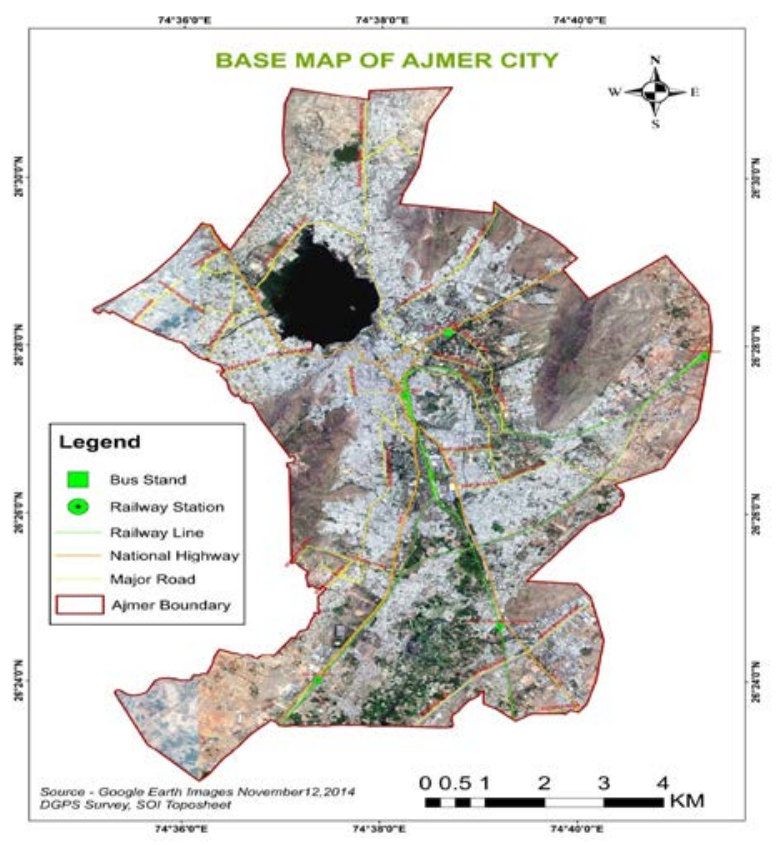

Fig. 2 Base Map of Ajmer City

This study presents the study findings based on the study objectives; including satellite imagery of the years 2000 and 2017, existing land use patterns map, ward wise population density map and impacts of urbanization on land use/ land cover.

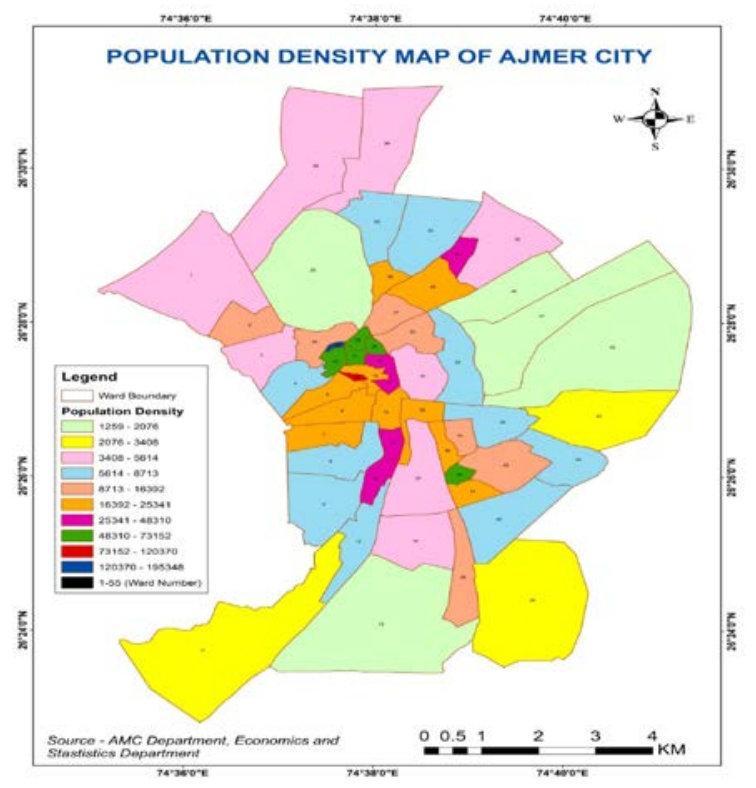

Fig. 2 Population Density Map

As per Ajmer Municipal Corporation, Ajmer city has 60 wards. The given population density map is showing the density of population residing in city area distributed among these 60 wards. Wards with highest population density are 20, 21, 22, 23, 28, 29 and 42 (Figure 3). These 
wards consist of major parts of recently developed Chandravardai Nagar, Subhash Nagar, Adarsh Naqgar and Madar Gate.

Wards with comparatively less population density are 10 , 15, 17, 18 and 51. These wards consist of the parts of Dargah area, Kesarganj, areas at the bottom of Tragarh hill like Ajayanagar, Bhagwaanganj and UIT quarters. These areas are very congested in terms of housing. Due to high congestion, vertical expansion of buildings is very common in these areas, since the areas are too small for horizontal expansion. As per the current Master Plan of Ajmer city, the area of the main city has now expanded outside these wards' boundary. The areas outside the main city are being developed due to this increased population. These areas are more systematic and well planned in terms of housing along with better facilities.

\section{A. Land Use in Ajmer City}

Comparative analysis of land use would indicate the extend of impact of population growth as the land use development is directly linked with the population size (Bernstein, J. D, 1993). The analysis of satellite imagery taken at different time periods (2000 and 2017) shows the changing land-use pattern in Ajmer city. The total area of Ajmer city is 81.70 sq.km as per the researcher's analysis. Residential use is the most pro-dominant land use of the master plan. The plan envisaged the development of 7250 acres of under residential use, but 6000 acres have developed during the plan period it is observed that this use has developed much faster than other uses as a result, areas set apart for other uses have been overtaken by residential use.

TABLE I LAND USE OF AJMER CITY

\begin{tabular}{|c|l|c|c|c|c|}
\hline \multirow{2}{*}{ S. No. } & \multirow{2}{*}{ Land Use } & \multicolumn{2}{|c|}{ Proposed in Master Plan1971-2001 } & \multicolumn{2}{c|}{ Actual In Master Plan2001-2023 } \\
\cline { 3 - 6 } & & Area in acres & \%age of development & Area in acres & \%age of Development \\
\hline 1 & Residential & 7250 & 50.8 & 6000 & 52.26 \\
\hline 2 & Commercial & 500 & 3.4 & 564 & 4.96 \\
\hline 3 & Industrial & 1560 & 10.8 & 586 & 5.10 \\
\hline 4 & Government & 120 & 0.9 & 140 & 1.22 \\
\hline 5 & Public/Semi-Public & 1750 & 12.2 & 1571 & 13.68 \\
\hline 6 & Recreational & 840 & 6.0 & 138 & 1.20 \\
\hline 7 & Transport & 2260 & 15.8 & 2483 & 21.60 \\
\hline & TOTAL & 14,280 & $100 \%$ & 11,482 & $100 \%$ \\
\hline
\end{tabular}

Source: Master Plan 1971-2001 and 2001-2023

In 1970-80 Shastri Nagar, Shastri Nagar Ext., Bhagwan Ganj, Vaishali Nagar, Anasagar Circular Road, Dhola Bhata residential project were developed. In 1980-90 Jwala Prasad Nagar, Arjunlal Sethi Nagar and M.D. Nagar colonies were planned. 1990-2005 witnessed the growth of H.B.U Nagar, B.K. Kaul Nagar, Chandravardai Nagar, and Maharana Pratap Nagar. 2005-2015 Witnessed the growth of Panchsheel Bloack A-E, Prithviraj Nagar Yojana, Pragati Nagar Kotra, Patrakar Colony, Kotra, Kayad.

The spatial analysis indicates that residential use has developed in almost all other use i.e. commercial and open space etc. The main reason for this is the development of residential use through cooperative societies, which have developed land in violation of master plan (Yadav M., 2017).

\section{B. Land Use and Land Cover in 2000 (Figure 4a)}

The image interpretation results are as follows,

1. In the year 2000, the built-up area has started replacing the agricultural land as per the land use/land cover map.

2. The encroachment of land can be seen around the centre of attraction of the city which is the Ana Sagar Lake and around hilly areas.

3. The total agricultural land was decreased by $57.94 \%$ and reached up to 47.34 sq.km.
4. Whereas the built-up area increased up to 16.12 sq.km which was $19.73 \%$ of the total land surface of the city.

5. There was some change in the amount of wasteland. Due to urban sprawl it is seen that the wasteland was used for built-up and mining purposes near hilly areas.

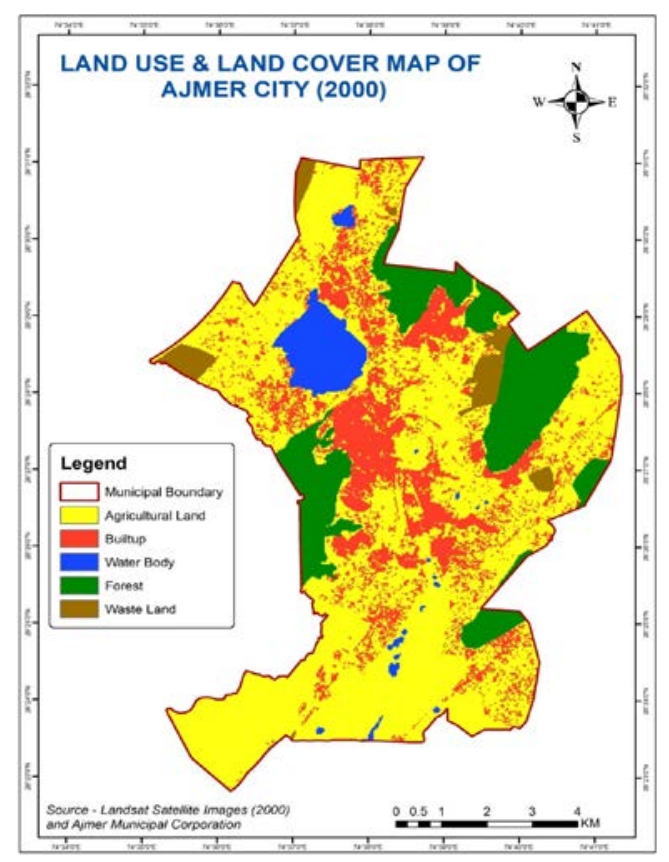

Fig. 3 Land Use And Land Cover of Ajmer City 2000 


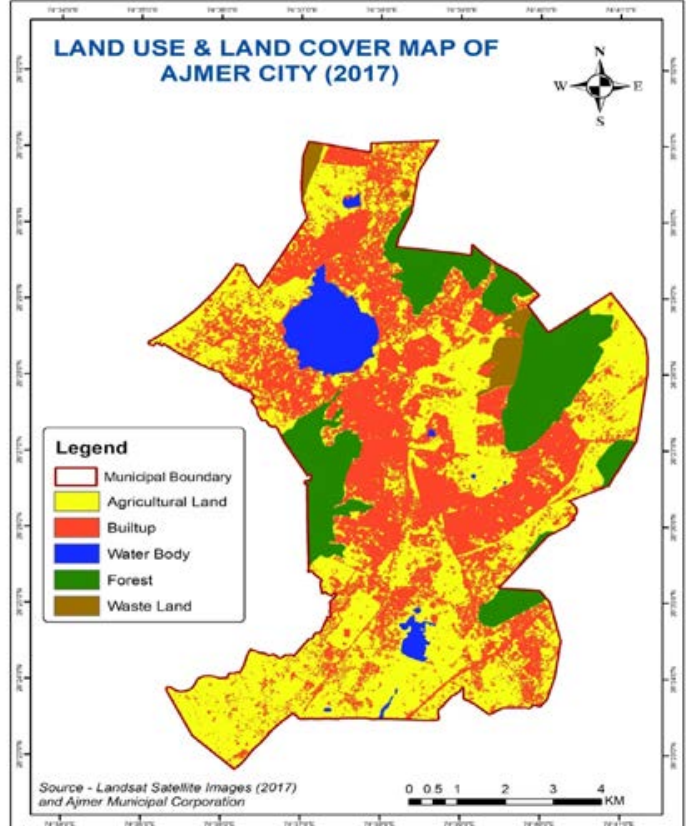

Fig. 4 Land Use And Land Cover of Ajmer City 2017

\section{Land Use and Land Cover in 2017 (Figure 4b)}

The image interpretation results are as follows

1. In the year 2017, the built-up area has replaced the huge agricultural land as can be seen in the land use and land cover map.

2. The cluster of settlement can be seen all over the central region of the city.

3. In 2017, the agricultural land remained 33.60 sq.km, which is only $41.12 \%$ of the total land surface of the city.

4. Whereas the built-up area has increased by 30.15 sq. km, which is $36.0 \%$ of the total city area.

5. Wasteland also kept on decreasing and remained 1.36 sq.km.

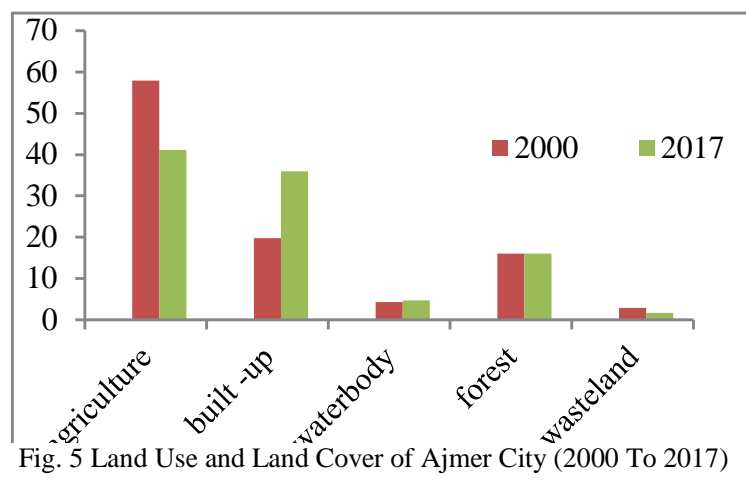

This is a graphical representation of land use and land cover area of Ajmer city (Figure 5), which clearly shows the changing land use patterns from the year 2000 to 2017. There is a continuous decrease in the agricultural land and continuous increase in built-up area from the year 2000 to 2017. There is also decrease in wasteland since the land is being used for industrial purposes. Interestingly, there is no much change in the land cover of forest and water body. The results demonstrate that over the entire study period, population of Ajmer city was increased from 485,197 to 542,321 between year 2001 to
2011. The growth rate of the population is varying in this period. There is a sudden increase in the population growth in 2001 which was 20.5\% in comparison to year 1991 which was only $7.6 \%$. But in the very next decade the growth rate decreased and reached up to $11.8 \%$ in year 2011. This variation in the growth rate shows that this changing pattern in the population of the study region might be due to the Rural-Urban migration.

\section{IMPACTS OF URBANIZATION ON ENVIRONMENT}

Due to urbanization the increasing demand for land, coupled with a limitation in its supplies, is a major cause for more conflicts over land use throughout the natural vegetation. Some of the major impacts of urbanization in Ajmer city are as follows:

The large chunks of productive agricultural land with very good amount of ground water, are now converting into a concrete jungle. The fertile land which was once under agricultural activities, has now become a market place.

Lack of access to planed space for the urban poor, has resulted in encroachment on the hill slopes especially on Taragarh hill and water bodies. The encroachment on hills especially along the course of natural drains lead to pollution and chocking of the drains and lead to change in the course of drain which affects the inflow into the lakes.

Kishangarh, is the main area of marble industries in India. The marble industries have not only provided occupation to large number of people but has also ignited the ways of attracting tourism industry at dumping yard situated at RICCO Industrial area. Over the year, the area swelled, stripping and affecting the locality of all its vegetation. Marble slurry destroys the soil cover and contaminates ground water, prohibiting vegetation (Lall V., 2017).

Mining activities being held in this region have huge impact on land surface, landscape, soil fertility and land use pattern. Both the agricultural and forest land has faced hazardous effect of mining activities. Land use pattern is also disturbed due to cut of forests and shifting of agricultural activities in mine areas.

The population growth also dropped many related problems such as acute shortage of accommodation, both residential and non-residential, traffic congestion lack of sanitation and other community facilities and amenities etc.

The cost of living in urban areas is very high. When this is combined with random and unexpected growth as well as unemployment, there is the spread of unlawful resident settlements represented by slums and squatters. Census 2011 records 59 slums areas in Ajmer city.

The overflow from Anasagar Lake which is the focal point of the city, is conveyed by Anasagar escape channel to Khanpura Pond. It is noticed that all drains in this Zone, have a major problem of waste water inflow and dumping of solid waste. Due to the absence of proper 
sewerage system the drains carry municipal wastewater and finally discharge into Anasagar Lake, thus resulting in poor water quality of the lake. Mostly the drains are choked with municipal solid waste, silt and silage. Apart from this, it is noticed that the hills surrounding Ajmer, have very steep slope and does not have adequate vegetation cover causing heavy run-off and soil erosion, which results in silting of drains and subsequently of the Ana Sagar.

Traffic congestion is a common problem in Ajmer because of narrow streets and uneven roads, the problem of traffic pressure is in very critical position in high density areas, the streets are so narrow that only single person at a time can enter inside. The traffic in the city usually becomes uncontrolled because of street traffic pressure. Main roads of the city are also less wide as compared to population and increase in the number of vehicles in city. Though to avoid the more pressure on the roads, bypass road is constructed on N.H.8 for Ajmer Beawar-Nasirabad. Ajmer bus stand is situated in the centre of city and therefore busses passes through the city. The centre of city Parao and Kesarganj area is situated and becomes grain market. In these areas small and big trucks are entering causing traffic congestion. Similarly, there is no adequate arrangement of parking in the city (Yadav M., 2017).

\section{CONCLUSION}

Urbanization took place with a high rate after industrial revolution in European countries, which continued to be increasing since then. Urbanization mainly includes secondary and tertiary sectors, primary activities like agriculture are not seen to be much popular in urban areas. Due to industrialization, agricultural lands are shrinking which ultimately leads to low productivity (Sherry, Mitra A. S. and Dutta B, 1981). India ranks second worldwide in farm output and her 50\% population are involved directly or indirectly in agricultural activities. Also, it is amongst the top Asian countries whose urban growth rate is at highest pace than any other developed country. But the concern is, with this high rate of increasing population how long will India be able to feed her population because of her slow agricultural growth caused by urbanization?

After reaching to the peak of industrialization, European countries are coming back to the agricultural activities. Because they have realized this fact that, for a long run, the country must be self-sufficient in all aspects; industrial as well as environmental. India, who has a great potential in agricultural sector is now witnessing drastic changes in land use pattern all over the country due to her increased population and urbanization. Although urbanization has several advantages like creation of employment opportunities, technological and infrastructural advancements, improved transportation and communication, quality of educational and medical facilities, and improved standards of living. However, extensive urbanization mostly results in adverse effects.

In the absence of proper planning, urban cities face several environmental problems such as unavailability of resources, environmental degradation, pollution, land degradation, exploitation of natural resources. High population leads to lack of employment, lack of housing and other infrastructure such as education, health care, sewers and water supply. In such situation, cities also become home to high concentrations of poverty and formulation of slums. In such situation there is a significant need of urban planning for the proper functioning of cities. In present urban era, we need a sustainable and environment friendly cities which could meet the requirements of individuals residing there and without on the cost of environment.

\section{REFERENCES}

[1] Aldington T., (1997). Urban and peri-urban agriculture: some thought on the issue of Land Reform, Settlement and Cooperatives, 2, 43-44.

[2] Bernstein, J. D., (1993). Land use considerations in urban environmental management. Urban management programme policy paper no. 12. Washington, D.C., The World.

[3] Bhatta, B., (1963). Analysis of Urban Growth and Sprawl from Remote Sensing Data; Springer-Verlag: Berlin/Heidelberg, Germany, 2010. Berger, P.L. Invitation to Sociology, Ringwood: Penguin.

[4] Cohen, B., (2006). Urbanization in developing countries: Current trends, future projections, and key challenge for sustainability. Technology in Society, 28, 63-80.

[5] Drakakis-Smith, David. (1996) "Third World Cities: Sustainable Urban Development II - Population, Labour and Poverty.” Urban Studies 33(4), 673- 701.

[6] Milan Kumar Yadav (Dr.) (2017). Population Growth and Environmental Degradation in Ajmer.

[7] Retnaraj, D., (1994). Pattern of Urbanization and Economic Performance in Kerala, The Asian Economic Review, 36(3).

[8] Sherry, Mitra A. S., and Dutta, B., (1981). Shifts in the Function of Cities and Towns in India 1961-71. Abhinav Publications, New Delhi.

[9] Shrestha, Nanda, R., \& Hartshorn, Truman, A. A New capitalist Perspective of Third World Urbanization and Economic Development, Rawat Publication, (Ltd), Jagamala Diddee. Vimala Ranga Swamy.

[10] Vandana Lall. (2017). Antarctica of Kishangarh: Boon or Bane. IJRASET, 5. 